\title{
El Salvador: conocer nuestro presente en nuestro pasado
}

En El Salvador, nuestro lenguaje político contemporáneo no se entendería sin conceptos como "República", "Ciudadanía", "Democracia", "Poder legislativo, judicial y ejecuti$v o^{\prime \prime}$, etc. Evidentemente, no se trata de simples palabras. Son ideas que nos remiten a los fundamentos políticos del Estado salvadoreño. Por otro lado, quienes disfrutamos del rico y diverso mundo de la academia, consideramos fundamental la libertad de pensamiento; el derecho a publicar y difundir nuestras ideas; el uso de la tolerancia para el diálogo abierto, crítico y bien fundamentado; etc. No obstante: ¿Cuál fue la trama histórica que hizo posible llevar a la práctica esos ideales? ¿En qué momento de la historia nos constituimos en República? ¿Cuál es la diferencia entre República y Democracia, o es que acaso significan lo mismo? Formalmente nos seguimos llamando República, pero hoy en día a nadie le interesa reivindicar ese ideal, como sí se reivindica el valor de la Democracia.

Esas y otras preguntas nos llevan, inexorablemente, al siglo XIX centroamericano y salvadoreño. Así como ahora escuchamos decir que somos hijos de la Guerra Civil que 
duró 12 años; también podemos afirmar, sin lugar a dudas, que seguimos siendo hijos, o nietos, del siglo XIX. Las bases que sostienen lo que hoy Ilamamos Estado salvadoreño se forjaron en aquella época. En ese sentido, cualquier indagación o reflexión sobre la génesis histórica de las ideas arriba planteadas nos llevará, necesariamente, a los procesos sociales, políticos y culturales que se dieron cita en las Provincias de Centroamérica en los años previos y posteriores a la independencia de España.

Este año, 2009, se desató toda una polémica en torno al decreto sancionado por algunos diputados de la Asamblea Legislativa, el cual aprobaba la lectura de la Biblia en los centros de educación pública. Algunos medios de comunicación salieron a las calles a recoger la opinión de la gente; muchos pastores evangélicos estaba felices - se frotaban las manos - con el decreto. Pero muchos quizás no sabían que con dicho decreto El Salvador estaba retrocediendo en una conquista con más de cien años de existencia: la educación laica. Desde 1880 el Estado inició una batalla por expulsar la enseñanza del catecismo de la Iglesia Católica de las escuelas públicas; lucha que no consolidó, al menos jurídicamente, hasta 1889, cuando se emitió un nuevo reglamento de educación primaria que ya no contempló la enseñanza de la doctrina cristiana. Algunos dirán que la lectura de la Biblia en ningún momento buscaba catequizar, sino formar en valores. En realidad, cualquier libro sagrado que ingrese a las aulas de las escuelas públicas estaría violando el carácter aconfesional del Estado y "el libre ejercicio de todas las religiones", derecho sancionado por el artículo veinticinco de la Constitución actual.

Los defensores del decreto hablaban de la necesidad de educar en valores; de ahí que, razonaban, la lectura de la Biblia en las escuelas proveería a los niños de "buenos" valores, y así tendríamos personas ejemplares, dignas de imitar, en definitiva, buenos ciudadanos.

"Educar buenos ciudadanos". Tampoco es un tema nuevo. Ya en mayo de 1874 el presidente Santiago González aprobaba la enseñanza de la Cartilla del ciudadano - escrita por el intelectual Francisco Esteban Galindoen las escuelas del país; la medida buscaba formar a los ciudadanos que el Estado demandaba. Formar a aquellos que serían los hacedores de la patria, ya fuere legislando, enseñando en las escuelas o gobernando. Educar al buen ciudadano significó para aquella época educar en el respeto a las leyes y al bien público. La moral republicana insistía en el respeto a las leyes y a la Constitución, puesto que de eso dependía la buena marcha de la República. Ser patriota en el sentido republicano de la época significaba velar por el orden y el bien público, esto era lo fundamental. 
Hoy, en lugar de estar sugiriendo más trabajo para los ya bien "atareados" profesores, habría que empezar a hacer ciertas cosas en apariencia triviales, pero tan importantes que hasta podríamos salvar vidas: que el conductor respete la "cebra" del peatón, que no se cruce la calle cuando el semáforo esté en rojo; educar desde el seno familiar en el respeto y la igualdad entre géneros; que los funcionarios públicos cumplan a cabalidad su trabajo; que los diputados verdaderamente trabajen por el bien público; aprender a no tirar la basura a la calle; que todos los empresarios -ipor fin!- paguen los impuestos; etc.

Volviendo al principio: el presente no es sin un pasado que lo constituya. El presente es justamente porque el pasado fue; en el presente se hace presente el pasado y se proyecta el futuro. Y las ideas, como las sociedades humanas, conservan su propia historia; una historia que no acontece al margen de los procesos históricos, sociales y políticos. Las ideas se deben a un contexto histórico plagado de intereses, visiones y poderes, y muchas veces en abierta o solapada pugna. De ahí que no encontraremos ideas puras; tocará estudiarlas siempre como seres "manchados" por los intereses, los sueños y las contradicciones de quienes hacen la historia. Y es en ese entramado histórico - que reúne ideas, intereses y poderes, a veces tan diversos y contradictorios; en sospechosas e impensables alianzas o en franca lucha fraticida - en el que nos vamos constituyendo como individuos, como hombres y mujeres, y como ciudadanos.

Estudiar nuestro pensamiento, nuestras ideas, significa remover las piezas, los fragmentos de nuestro pasado; significa irrumpir entre la historia ya contada y aquella que aguarda escondida o ensombrecida a la espera de ser reconstruida. El escritor argentino Ernesto Sabato decía que sólo cuanto han alcanzado cierta madurez los pueblos se lanzan a la tarea de conocer su propia historia, sin miedos y sin prejuicios. Estudiar nuestro pasado significa asumir nuestros errores, no sentir vergüenza ante los sueños inconclusos de aquellos hombres y mujeres que nos precedieron.

Y, por supuesto, conocer toda nuestra historia. Piénsese, por ejemplo, si acaso hay salvadoreños estudiando la Guerra Civil que nos dejó cerca de cien mil muertos y sin personas de la talla de Oscar Arnulfo Romero e Ignacio Ellacuría.

Conocer nuestra historia es conocernos a nosotros mismos. Sólo mediante el desciframiento del pasado podremos comprender por qué hoy somos como somos y lo que somos. 